\title{
Students' Perception on the Teacher's Orientation, Mentoring and Ongoing Support in Project-Based Learning: A Case Study in Vietnam
}

\author{
Le Tan Cuong \\ Faculty of English Linguistics and Literature \\ University of Social Sciences and Humanities- Vietnam National University, HCM, Vietnam \\ E-mail: cuonglt@hcmussh.edu.vn
}

Received: August 31, 2019 Accepted: September 15, 2019 Published: September 17, 2019

doi:10.5296/ijele.v7i2.15462 URL: https://doi.org/10.5296/ijele.v7i2.15462

\begin{abstract}
Project-Based Learning (PBL) has for long been an effective approach in education. It is widely incorporated in various educational contexts. While great emphasis has been put on its positive influences on students' learning, teachers and students' perspectives of the approach, and challenges in the process of implementing the approach in various contexts, interest in how students think of the teacher's contribution remains fairly limited. The current study, therefore, is an effort to fill the gap by placing its focus on students' perception on the teacher's orientation, mentoring and ongoing support in Project-Based Learning in a Vietnamese context. Participants in the study are 174 freshmen coming from 4 seperated classes in the same course named Presentation skills in two different school years in Faculty of English Linguistics and Literature, University of Social Sciences and Humanities- Vietnam National University, HCMC, Vietnam. Data is systematically collected from a web-based questionnaire and students' end-of-course reports in 2018 and early 2019. The results of the study reveal that the majority of the students highly appreciate and benefit from the teacher's orientation, mentoring and ongoing support in PBL. Suggestions from the participants in the study are also noted as good references for the teacher's upcoming teaching stratergies. The study contributes to the current understanding of PBL in education and provides solid support for further exploitation of other aspects of the approach in Asian contexts.
\end{abstract}

Keywords: Project -Based Learning, Students' perception, Presentation skills 


\section{Introduction}

Project-Based Learning (PBL) has been common in education for a long time and obtained its importance in the field. PBL has been applied in various teaching contexts in the world. Thomas (2000) claims that PBL is effective in diverse contexts. In Vietnam, the approach has also been part of a great number of teaching strategies, especially in higher education. Many scholars in the field share the idea that PBL not only positively influences students' academic performance but also helps them enhance 21st century skills (Musa et al., 2011) (Essien, 2018). However, recent research seems to have prioritized positive influences the approach on learning, on teachers and students' perspectives, and challenges in its implementation rather than on how students reflect on teachers' roles in such an approach. The current study, therefore, aims to fill the gap by exploring students' perception on the teacher's orientation, mentoring and ongoing support in Project-Based Learning in a Vietnamese context which is, in this case, at Faculty of English Linguistics and Literature- University of Social Sciences and Humanities, Vietnam National University, HCMC (EF-USSH, VNUHCM). The paper firstly reviews the implementation in PBL in education in some countries in general and in Vietnam in particular. The author then reports on how PBL is deployed in the course of Presentation skills in EF-USSH, VNU HCM. Discussions on the effectiveness of PBL and the role of the teacher in PBL in the investigated context come as the next part of the paper. Recommendations are elaborated in the last part of the paper as an effort to provide faculty deans and teachers with ideas on how to effectively apply and better PBL in their teaching contexts. Using data from a web-based questionnaire and students' end-of-course reports in two school years of 2018 and 2019, the study confirms the feasibility and efficiency of PBL in a Vietnamese context. Also, the study highlights students' positive perception on the role of the teacher in orienting, mentoring and supporting in PBL in the investigated context. The study hopefully adds in more references to the current understanding of PBL and its practice of applying the approach in education, especially in Asian contexts.

\section{Literature Review}

\section{a. Project-Based Learning and its influences in education}

Project-Based Learning (PBL) is known as a learning method based on constructivism (Hmelo-Silver, 2004). The approach has its root back to John Dewy's work which appeared more than a hundred year ago (Krajcik \& Blumenfeld, 2006). There have been different perspectives on PBL. Though the perspectives seem different to some extent, most of them come to an agreement that PBL provides students with better chances to get involved in real-life situations, learn new things, actively apply what they learn from school and fully develop necessary skills which they may need in their future careers. While Holm (2011) defines PBL as student-centered instruction that occurs over an extended time period, during which students select, plan, investigate and produce a product, presentation or performance answering a real-world question or responding to an authentic challenge, Felipe et al (2016) shares the belief that PBL is a well-suited approach actively engaging students with real world problems and challenges in order to acquire deeper understanding. In addition, García 
(2016) states that Project-based learning is a response to students' lack of contextualization and over-simplification and excessive abstraction of learning in schools. Amamou \& ChenitiBelcadhi (2018) show their agreement to García's statement in their recent work that PBL allows learners to be involved in the analysis of a given project and the search for possible contextualized learning. They consider the approach as a way to fully engage students in the construction of their knowledge by interacting with their peers and their environment. By this way, PBL is not merely a supplementary activity to boost students' learning, but also a fundamental part of the curriculum and it involves the development of skills (Bell, 2010).

Since it was first introduced in the field of education, PBL has proven its importance in various aspects of students' learning process. Firstly, PBL helps students develop necessary learning skills. According to Tally (2015), PBL helps students develop a variety of valuable 21 st century competencies and the teachers in PBL are able to set students up for success by helping them build a solid foundation for these skills through the use of scaffolds. Musa et at., (2011) in a study conclude that Project -Based Learning has successfully exposed students to various skills such as team-working, managing conflicts, decision making, and communication skills. Similarly, Essien (2018) reports that PBL improves students' critical thinking ability, independent study skill, personal and social responsibility, and strong communication skills. For Simpson (2011), PBL enhances students' learning skills (teamwork, higher-order thinking and presentation skills) together with self-confidence. On the other hand, Pinzon (2014) states that Project Based Learning contributes to enhance not only students' motivation to learn English, but also it promotes individual and social values to improve the coexistence. Secondly, PBL is the foundation for students' language development. Essien (2018) considers Project-Based Learning as an effective teaching methodology to enhance students' English language ability and provide them with opportunities to learn with the same ways that they may use in their future careers. PBL can also help encourage learners to use language skills and support learners' confidence in using English because students use various skills to acquire, analyze, and synthesize information as they worked on their project (Poonpon, 2017). Besides, Wahyudin (2016) in the recent study carried out in one of higher education institutions in Bandar Lampung, Indonesia reports that there is a notable positive effect obtained from the use of PBL during the learning process and recommends that practitioners apply PBL as an alternative way to teach ESP class, especially at the undergraduate level because PBL contributes to the increase of students' L2 oral performance, especially in terms of comprehension and fluency. Miller et al., (2012) adds in more specific details in her report that students in their study improve general English language skills by completing the project with good results as follows: oral skills, including presentation skills $(73 \%)$ and pronunciation (67\%), grammar (43\%), reading (44\%), writing (44\%) and listening skills (51\%). Moreover, Marwan (2015) in another study reveals that students could experience a more interesting and meaningful learning in a PBL English class and were also becoming highly motivated to use English more intensively while exposed to this teaching approach. Together with this, in Habók \& Nagy (2016), benefits of PBL were observed in the development of cognitive and metacognitive strategies and the increase of motivation, which resulted in an increase in English proficiency. Thirdly, PBL provides students with chances to apply theory into practice and explore the outside world. Kean et at., 
(2014) agrees to this perspective that the dynamic approach provides an all-round enriching education where students are inspired to explore, investigate, consider alternatives, understand their world and apply what they learn to real-life experiences. Students, therefore, thrive on the greater flexibility of project learning.

In such an effective approach, the teacher is the determinant of success. As the focus of PBL is student-centered, the teacher's role is no longer as dominant as it was, but the role of a guide, adviser, motivator, facilitator and evaluator (Jalinus, et al., 2017). In a case study aimed at exploring students' and teachers' perceptions of a project-led education course carried out in a Portuguese university, findings reveal that a clear recognition of the benefits of the approach to both the teaching staff as well as the students (Lima et al., 2007).

As PBL has been widely acknowledged as an effective approach to enhance students' academic performance and learning skills, research on PBL, especially on how students taking part in PBL reflect on their learning process with their teacher's scaffold, in such a developing country like Vietnam promisingly adds in interesting values to the current literature.

\section{b. Project-Based Learning in Vietnam}

There have been a considerable number of researches in Vietnam investigating the effectiveness of PBL. Van Lam (2011) insists that PBL is a beneficial approach to be applied at university in Vietnam and should be widely applied at university where students need to enhance necessary authentic knowledge and skills for their life and work. One year later, Diem (2012) adds to the literature of PBL in the country in her study among second-year students of English working in groups as news editors to produce news and comes up with the conclusion that changes were found not only language competence and attitude, but also in some important soft skills. Additionally, Ngo (2014) reports on the reality in Vietnam that unlike English as a second language context, the English in this country is learned as a foreign language so most Vietnamese learners have few opportunities to use English in their daily life. Therefore, he strongly believes PBL is really suitable for this area subject for that English is used as a work means. Moreover, Felipe, et al. (2016) in a study at RMIT Vietnam conclude that students do benefit from project-oriented courses and activities, and suggest that Vietnamese students are able to integrate its principles effectively in learning. $\mathrm{Na}$ (2017) in an investigation among 30 students and 3 instructors in an English for Business course in Vietnam also reveals positive effects on language, soft skills, and professional development thanks to PBL. The current evidence triggers the author's curiosity about the possibility of applying PBL in Vietnamese context.

\section{Purpose of Study}

The purpose of this study is to investigate students' perception on the role of the teacher in Project-Based Learning in a Vietnamese context. Using the data collected a web-based questionnaire and students' end-of-course reports in 2018 and 2019, the author seeks answers for the two following questions: 
- In what ways does Project-Based Learning help enhance students' academic performance in a course of presentation skills in a Vietnamese context?

- How do students in the course think of the teacher's orientation, mentoring and on-going support in Project-Based Learning?

\section{Research Methodology}

\section{a. Population and sampling}

The research setting in the study is at Faculty of English Linguistics and LiteratureUniversity of Social Sciences and Humanities, Vietnam National University, HCMC. As a national university, USSH HCM has more than 16.000 students of 30 majors. Faculty of English Linguistics and Literature which is taking the responsibility of training more than 3000 students is the largest unit in the entire university. The participants in the study are 174 English-major students from 4 different classes. The number consists of 77 students in two classes in 2018 and 97 students in another two in 2019. They all take part in the same course entitled Presentation skills which is in 2nd semester in their curriculum. The course is designed to prepare students for success in typical public speaking situations and provide them with practical skills of public speaking, fundamental principles of organization, research and delivery that are needed for effective speeches. After the course, students are expected to master techniques in effectively preparing, organizing, and delivering different types of speeches in both academic and other settings, techniques of oral presentation and persuasion, the use of visual aids (pictures, charts, graphs or PowerPoint) to enhance speaker presentations and cultural conventions and the use of verbal and non-verbal messages in public speeches.

\section{b. Procedure of the course and students' projects}

In the 12-week course of Presentation skills in the study (5 periods of 45 minutes per week), students are expected to go through the procedure in Table 1 (see appendix 1).

This is a three-credit course and students are required to have completed all the four-skill courses before this one. The three main materials used in the course are as follows:

- Lester, A. (2009). Present for Success: A powerful approach to building confidence, developing impact and transforming your presentations. Marshal Cavendish International.

- Lucas, Stephen, E. (2009). The art of public speaking (10th ed.). McGraw-Hill. (Chapters $4,5$ and 6$) \cdot$

- Powell, M. (2002). Presenting in English: How to give successful presentations. Thompson.

To pass the course, students are expected to satisfactorily meet the grading basis in Figure 1 (see appendix 5). Students' performance in the presentation is scored based on the following 
criteria:

- Content \& Organization

- Delivery manner (volume, rate, pronunciation, body language)

- Language use (grammar \& vocabulary)

- Visual aids

- Question handling

In term of the project, students take over a 4-week mission from week 4-7 in the course procedure. Products of the projects are a 10-minute group presentation, a project report reflecting what they have gained from the project and video clips of the interviews. Details could be found in Table 2 (see appendix 2).

\section{c. Instrumentation}

A web-based questionnaire and students' end-of-course reports are the sources for data used in the study. The questionnaire which is sent to the students via google form in their last week of the course includes 25 questions investigating students' self-evaluation and feedback before and after the course, which quantitatively provide the author with valuable evidence of how students make progress after taking part in PBL in the course. On the other hand, students' end-of-course shows students' achievement in a quantitative way. The reports are available one week after the course. The two sources of data to some extent generalize students' improvement thanks to the application of PBL in the course.

\section{d. Data collection and analysis}

Based on data collected using the questionnaire and students' end-of-course reports, PBL is found to have made great influences on students' academic performance during the course of Presentation skills in a Vietnamese context.

The end-of-course reports reveal a lot about the students' academic performance. Table 3 (see appendix 3) and table 4 (see appendix 4) shows that PBL really helps improve students' academic performance. Only 8 out 43.5 equivalent to $18,4 \%$ students on average $(n=174)$ get the scores from 8.5 to 10 in the mid-term test while the number turns to 19 out 43.5 equivalent to $43.7 \%$ after the course. The application of PBL helps students with scores from 8.5 to 10 improve $25.3 \%$ their academic performance. On the other hand, the number of students with the scores of 5-7 decrease from 13.75 equivalent to $31.6 \%$ students on average $(n=174)$ to 11.25 equivalent to $25.8 \%$. The number shows that PBL helps lower $5.8 \%$ students with scores from 5-7. The approach clearly betters students' academic performance.

Together with improved academic performance, students' feedbacks on the teacher's roles in orientation, mentoring and ongoing support have also been noted to be positive. The questionnaire shows that before the course of Presentation skills with PBL, only 32,8\% students (in 2018) and 31,9\% (in 2019) have motivation in learning, but the numbers in the same item after the course exceeds 82,7\% (in 2018) and 87,5\%, taking the year of 2019 as an 
illustration in Figure 2 (see appendix 6).

Additionally, students' confidence and team-working skills are noted to be positive. Students' confidence shows a considerable jump from $32,7 \%$ to $65,4 \%$ in 2018 and $30,6 \%$ to $66,7 \%$ in 2019. Furthermore, great improvement is noted from $36,4 \%$ to $83,7 \%$ in 2018 and $37,6 \%$ to $83,3 \%$ in 2019 in students' team-working skills. Besides, presentation skills improve impressively from $20 \%$ to $78,2 \%$ in 2018 , and $22,2 \%$ to $73,6 \%$ in 2019 (see appendix 7). This perfectly meets the outcomes of such a course.

Taking the data in Figure 4 (see appendix 8) as an illustration of students' learning satisfaction, the number reaches an impressive level as roughly $75 \%$ participants of the study are happy with the teacher's performance in the course. Students' perception on the teacher's orientation, as can be seen in Figure 5 (see appendix 9), is also worth discussing as 90,3\% of the participants appreciate the values of the teacher's orientation activities during the course. In term of the teacher's mentoring, participants rate $40,3 \%$ for "helpful" and $56,9 \%$ for "extremely helpful" in their responses, which could partly help explain what might have enabled the students to achieve great improvement in the course.

Another aspect that contributes to the success of PBL in this context is the teacher' ongoing support. Students in the investigation face a number of challenges during the process of PBL, so the teacher's ongoing support plays an indispensable role in getting the students back to the right tracks. The results of the study reveal that 90,3\% participants believe their teacher's ongoing support in the course are "extremely helpful" and "helpful".

\section{Discussion}

Simpson (2011) states that PBL requires a gradual shift in teaching methodology designed to suit the background of both teachers and learners and the adjustments will help enhance the effectiveness in the application and implementation of PBL in a foreign language classroom. In Vietnamese context, the teacher does make great efforts to fill the gap and lead the students to a higher level. The evidence found the study indicates that PBL shows its positive influences in enhancing students' presentation skills in the investigated context. The successes of the students have their root back from the teacher's orientation, mentoring and ongoing support throughout the process of PBL in the course. Students in the study highly appreciate the great contribution of the teacher in preparing them for Project-Based Learning in the course.

\section{Conclusion}

The findings in the current study are consistent with previous research that acknowledge the great significance of PBL in education in general and in language learning in particular. In the investigated context, PBL helps improve students' academic performance as well as essential skills that they may need in their future career path. The added values can probably be found in the study is students' positive perception on the role of the teacher in PBL. The students, as 
can be found in their responses in the questionnaire, highly value the teacher's orientation, mentoring and ongoing support during the process of carrying out PBL in the course. Learning satisfaction is also noted in students' feedback in the study, which is a big plus of the approach when it is implemented in the context. Though there are still a number of challenges to incorporating PBL in a Vietnamese context, the approach is a possible strategy to innovate teaching and learning. Further investigation on students' perception on the role of the teacher in PBL in other contexts may help deepen understanding about the approach and put forward more insights on how to utilize the appriach in various teaching contexts.

\section{References}

Amamou, S., \& Cheniti-Belcadhi, L. (2018). Tutoring in Project-Based Learning. Procedia Computer Science, 126, 176-185.

Bell.S, (2010). Project-based learning for the 21st century: skills for the future. Clearing House, 83, 39-43.

Diem, H. T. N. (2012). Making News: A Successful Example of Project-Based Learning1. Language Education in Asia, 2012, 3(1), 96, 105.

Essien, A. M. (2018). The Effects of Project-Based Learning on Students' English Language Ability. In The 2018 International Academic Research Conference, Vienna.

Felipe, A. L., Amouroux, E., Pham, T., \& Stojcevski, A. (2016). Vietnamese Students Awareness towards a Project Based Learning Environment. In 8th International Symposium on Project Approaches in Engineering Education/14th Active Learning in Engineering Education Workshop, At Guimaraes, Portugal (pp. 320-324).

García, C. (2016). Project-based learning in virtual groups-collaboration and learning outcomes in a virtual training course for teachers. Procedia-Social and Behavioral Sciences, 228, 100-105.

Habók, A., \& Nagy, J. (2016). In-service teachers' perceptions of project-based learning. Springer Plus, 5(1), 83.

Hmelo-Silver CE. (2004). Problem-based learning: what and how do students learn? EducPsychol Rev, 16(3), 235-266.

Holm M. (2011). Project-based instruction: a review of the literature on effectiveness in Prekindergarten through 12th grade classrooms. In Sight RivierAcad J, 7(2), 1-13.

Jalinus, N., Nabawi, R. A., \& Mardin, A. (2017, September). The Seven Steps of Project Based Learning Model to Enhance Productive Competences of Vocational Students. In International Conference on Technology and Vocational Teachers (ICTVT 2017). Atlantis Press.

Kean, A. C., \& Kwe, N. M. (2014). Meaningful learning in the teaching of culture: The project-based learning approach. Journal of Education and Training Studies, 2(2), 189-197. 
Krajcik, J. S., \& Blumenfeld, P. C. (2006). Project-based learning (pp. 317-34).

Lester, A. (2009). Present for Success: A powerful approach to building confidence, developing impact and transforming your presentations. Marshal Cavendish International.

Lima, R. M., Carvalho, D., Assunção Flores, M., \& Van Hattum-Janssen, N. (2007). A case study on project led education in engineering: students' and teachers' perceptions. European journal of engineering education, 32(3), 337-347.

Lucas, Stephen, E. (2009). The art of public speaking (10th ed.). McGraw-Hill. (Chapters 4, 5 and 6).

Marwan, A. (2015). Empowering English through Project-Based Learning with ICT. Turkish Online Journal of Educational Technology-TOJET, 14(4), 28-37.

Miller, L., Hafner, C. A., \& Fun, C. N. K. (2012). Project-based learning in a technologically enhanced learning environment for second language learners: Students' perceptions. E-Learning and Digital Media, 9(2), 183-195.

Musa, F., Mufti, N., Latiff, R. A., \& Amin, M. M. (2011). Project-based learning: Promoting meaningful language learning for workplace skills. Procedia-Social and Behavioral Sciences, 18, 187-195.

Na, Đ. C. (2017). Project-based learning in an English for business classroom. In 8th International Conference on TESOL, Ho Chi Minh City, Vietnam.

Pinzon,C. R. J. (2014). English teaching through project-based learning method, in rural area. Cuadernos de lingüísticahispánica, (23), 151-170.

Poonpon, K. (2017). Enhancing English skills through project-based learning. The English Teacher, 10.

Powell, M. (2002). Presenting in English: How to give successful presentations. Thompson.

Simpson, J. (2011). Integrating project-based learning in an English language tourism classroom in a Thai university.

Tally, T. (2015). The challenges of implementing project-based learning in the 21 st century classroom.

Thomas JW. (2000). A review of research on PBL. San Rafael, CA. http://www. bobpearlman.org/Best Practices/PBL_Research.pdf. Accessed 9th July 2019

Van Lam, N. T. (2011). Project-based learning in teaching English as a foreign language. VNU Journal of Foreign Studies, 27(2).

Wahyudin, A. Y. (2016, November). The effect of project-based learning on L2 spoken performance of undergraduate students in English for Business class. In Ninth International Conference on Applied Linguistics (CONAPLIN 9). Atlantis Press. 


\section{Appendices}

Appendix 1

Table 1. Procedure of the course and students' projects

\begin{tabular}{|c|l|}
\hline Week & \multicolumn{1}{|c|}{ Modules } \\
\hline 1 & Course introduction and project guidelines \\
\hline 2 & Planning your presentation \\
\hline 3 & Organizing and outlining \\
\hline 4 & Using language, projecting your voice and body language \\
\hline 5 & Using visual aids \\
\hline 6 & $\begin{array}{l}\text { Creating PowerPoint slides and script writing } \\
\text { Mid-term presentation (Individual) }\end{array}$ \\
\hline 7 & Managing the environment \\
\hline 8 & Consultation \\
\hline 9 & $\begin{array}{l}\text { Trouble shooting } \\
\text { Group presentation (Project based) }\end{array}$ \\
\hline 10 & Q \& A handling \\
\hline 12 & Consultation \\
\hline
\end{tabular}

Appendix 2

Table 2. Description of the group project

- Work in groups of 3-5 students

\section{Project description}

- Choose a favorite topic relevant to the course of Presentation skills

- Design a questionnaire of no more than 10 questions related to one topic which will be the one that students make a 10-minute group presentation

- Interview 10 native speakers about the topic using the questionnaire and film the whole process.

- Write a report focusing on three aspects: Description of the places and interviewees, the procedure of conducting the project and self-evaluation from the project 
Appendix 3

Table 3. Students' midterm scores

\begin{tabular}{|l|c|c|c|c|c|}
\hline \multirow{2}{*}{$\begin{array}{c}\text { Score } \\
\text { (Mid) }\end{array}$} & $\begin{array}{c}2018 \\
\text { morning }\end{array}$ & $\begin{array}{c}2018 \\
\text { afternoon }\end{array}$ & $\begin{array}{c}2019 \\
\text { morning }\end{array}$ & $\begin{array}{c}\text { Classess } \\
\text { afternoon }\end{array}$ & \multirow{2}{*}{ Mean } \\
\cline { 2 - 6 } & 2 & 2 & 0 & 0 & 1 \\
\hline $9.5-10$ & 12 & 9 & 5 & 2 & 7 \\
\hline $8.5-9$ & 20 & 20 & 20 & 27 & 21.75 \\
\hline $7.5-8$ & 1 & 11 & 17 & 14 & 10.75 \\
\hline $6.5-7$ & 0 & 0 & 6 & 6 & 3 \\
\hline $5-6$ & 0 & 0 & 0 & 0 & 0 \\
\hline $\begin{array}{l}\text { Under } \\
5\end{array}$ & 35 & 42 & 48 & 49 & 43.5 \\
\hline Total & 20 & & & \\
\hline
\end{tabular}

Appendix 4

Table 4. Students' final term scores

\begin{tabular}{|l|c|c|c|c|c|}
\hline \multirow{2}{*}{$\begin{array}{c}\text { Score } \\
\text { (Final) }\end{array}$} & $\begin{array}{c}|c| \\
\text { morning }\end{array}$ & $\begin{array}{c}2018 \\
\text { afternoon }\end{array}$ & $\begin{array}{c}2019 \\
\text { morning }\end{array}$ & $\begin{array}{c}\text { Classess } \\
\text { afternoon }\end{array}$ & Mean \\
\cline { 2 - 6 } & 17 & 13 & 0 & 0 & 7.5 \\
\hline $9.5-10$ & 15 & 13 & 10 & 8 & 11.5 \\
\hline $8.5-9$ & 1 & 16 & 16 & 20 & 13.25 \\
\hline $7.5-8$ & 2 & 0 & 16 & 16 & 8.5 \\
\hline $6.5-7$ & 0 & 0 & 6 & 5 & 2.75 \\
\hline $5-6$ & 0 & 0 & 0 & 0 & 0 \\
\hline $\begin{array}{l}\text { Under } \\
5\end{array}$ & 35 & 42 & 48 & 49 & 43.5 \\
\hline Total & & & & & \\
\hline
\end{tabular}


Appendix 5

\begin{tabular}{llllll}
\hline $\begin{array}{l}\text { Assessment } \\
\text { Criteria }\end{array}$ & Percent & Points & Score & $\begin{array}{l}\text { Percent of } \\
\text { final grade }\end{array}$ & Note \\
\hline $\begin{array}{l}\text { Group presentation (3-5 min./group) } \\
\begin{array}{l}\text { Mini individual presentation 1 } \\
(3 \text { min./student) }\end{array}\end{array}$ & $\begin{array}{l}50 \% \\
\mathbf{5 0 \%}\end{array}$ & $\mathbf{1 0}$ points & $\begin{array}{l}\text { Midterm } \\
\text { score }\end{array}$ & $30 \%$ & \\
\hline $\begin{array}{l}\text { Mini individual presentation 2 } 3 \\
\text { min./student) }\end{array}$ & $30 \%$ & $\mathbf{1 0}$ points & $\begin{array}{l}\text { Final } \\
\text { score }\end{array}$ & $70 \%$ & $\begin{array}{l}\text { To be computed } \\
\text { by the }\end{array}$ \\
$\begin{array}{l}\text { Final individual presentation } \\
(5 \text { min./student) }\end{array}$ & $\underline{\mathbf{7 0 \%}}$ & & & & $\begin{array}{l}\text { University } \\
\text { Admission Office }\end{array}$ \\
\hline & $\mathbf{1 0 0} \%$ & & & $\mathbf{1 0 0 \%}$ & \\
\hline
\end{tabular}

Figure 1. Grading basis for the course of presentation skills

Appendix 6

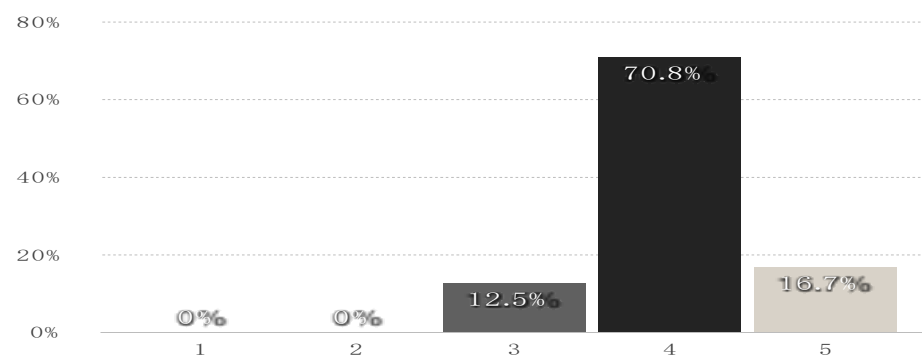

Figure 2. Students' confidence in the course in 2019

Appendix 7

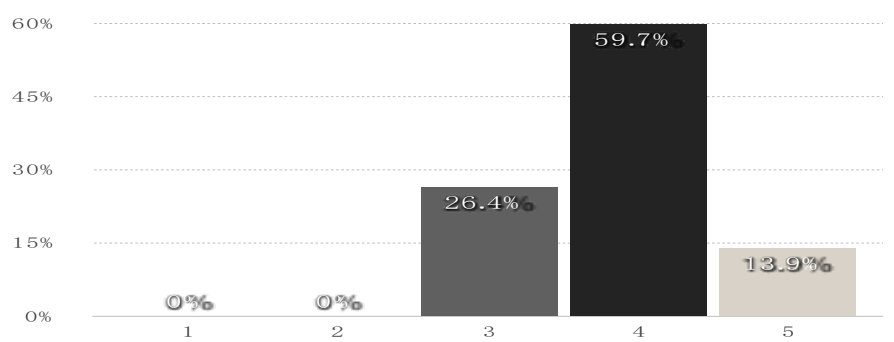

Figure 3. Students' presentation skills in 2019 
Appendix 8

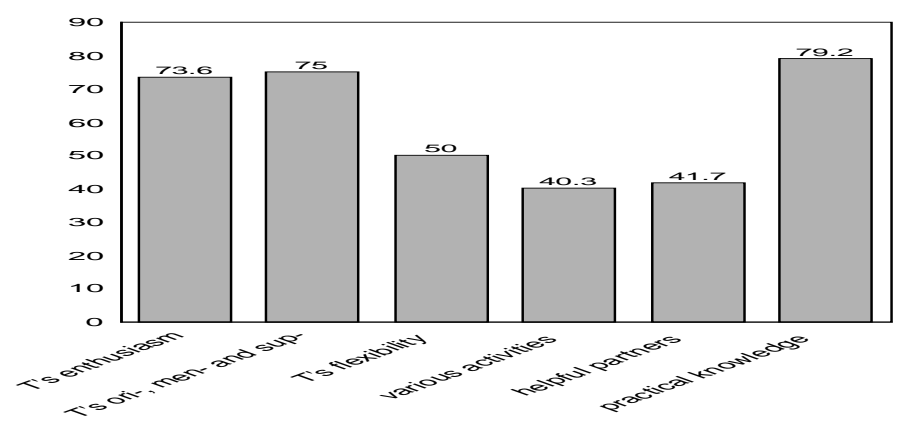

Figure 4. Students' learning satisfaction in the course in 2019

Appendix 9

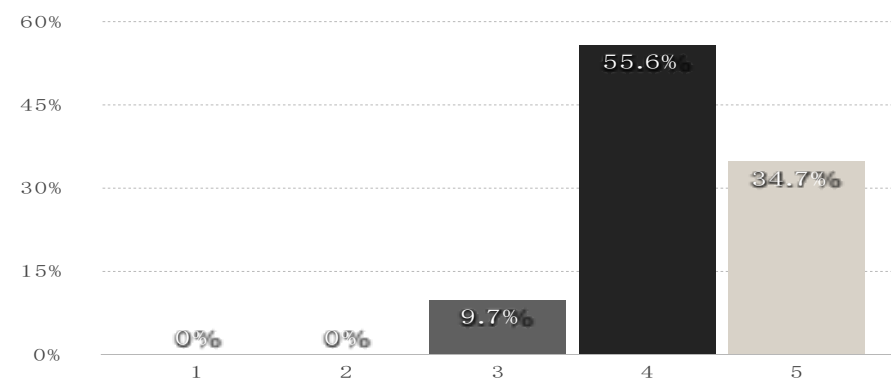

Figure 5. Students' perception on the teacher's orientation in the course in 2019

\section{Copyright Disclaimer}

Copyright for this article is retained by the author(s), with first publication rights granted to the journal.

This is an open-access article distributed under the terms and conditions of the Creative Commons Attribution license (http://creativecommons.org/licenses/by/3.0/). 